\title{
Hydration of casein micelles: kinetics and isotherms of water sorption of micellar casein isolated from fresh and heat-treated milk
}

\author{
BY MAX RÜEGG AND BERNARD BLANC \\ Federal Dairy Research Institute, $\mathrm{CH}-3097$ Liebefeld-Berne, Switzerland \\ AND MADELEINE LÜSCHER \\ Department of Inorganic and Physical Chemistry, University of Berne, CH-3012 \\ Berne, Switzerland
}

\begin{abstract}
SUmmaRY. Water vapour sorption isotherms of casein micelles prepared from raw milk and various heat-treated milks were determined. The equilibrium water contents of the heated preparations were markedly lower than that of the raw-milk casein over the whole range of vapour pressures studied. An analysis of the sorption isotherms in the relative vapour pressure range $0 \cdot 1-0 \cdot 45$, according to the Brunauer, Emmett \& Teller (1938) equation, showed that there were significant differences between preparations in the computed monolayer contents. Differences in the rates of water sorption were also observed between the different preparations.

As judged from the amount of absorbed water, the influence of the heating methods could be ranked in the order: HTST $\left(92^{\circ} \mathrm{C}\right) \simeq \mathrm{UHT}$ (direct) $<$ UHT (indirect) $<$ HTST $\left(72^{\circ} \mathrm{C}\right)$.
\end{abstract}

The structure and stability of casein micelles in an aqueous environment are closely related to their surface properties. The number and geometry of polar groups together with the distribution of hydrophobic regions determine the nature and amount of water binding and consequently the stability and reactivity of the micelles. Changes in the chemical and physical characteristics of the surface of casein micelles which take place when milk is being processed should therefore be apparent from comparisons and analyses of water vapour sorption isotherms. Measurements of sorption isotherms reveal possible differences in the amount of adsorbed water and may be used to study kinetic and energetic aspects of the water binding process (Crank \& Park, 1968; Kuntz \& Kauzmann, 1974).

This investigation was undertaken to study the hydration of natural casein micelles and to determine the effect of various heat treatments such as hightemperature short-time pasteurization (HTST) and ultra-high-temperature (UHT) processing on the hydration of micellar casein.

\section{EXPERIMENTAL}

Casein micelles used for this study were separated by ultracentrifugation (Rüegg \& Blanc, 1976) from fresh and HTST pasteurized milk $\left(15 \mathrm{~s}\right.$ at $72{ }^{\circ} \mathrm{C}$ and $20 \mathrm{~s}$ at $\left.92{ }^{\circ} \mathrm{C}\right)$, and from milk treated with direct UHT steam injection $\left(2.4 \mathrm{~s}\right.$ at $\left.150^{\circ} \mathrm{C}\right)$ and 


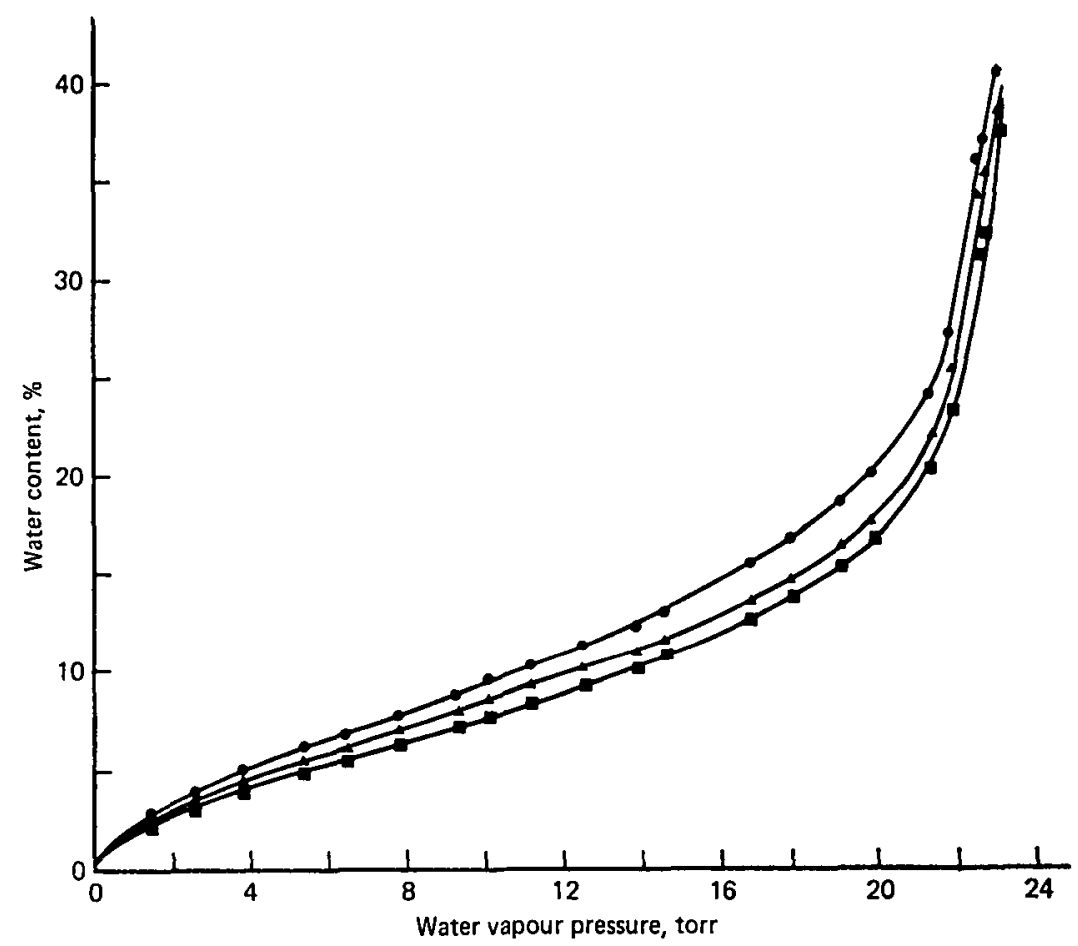

Fig. 1. Water sorption isotherm of micellar casein at $25^{\circ} \mathrm{C}$ from untreated $(O)$, high-temperature short-time pasteurized (HTST $92^{\circ} \mathrm{C}, \Delta$ ) and indirect ultra-high-temperature (UHT indirect, 口) processed milk.

indirect UHT heating techniques $\left(141{ }^{\circ} \mathrm{C}, 15 \mathrm{~s}>100^{\circ} \mathrm{C}\right)$. All milk samples were obtained from the same stock of fresh milk from Simmental cows, and were homogenized at $20 \mathrm{MPa}$. The washed casein preparations were freeze-dried and their water vapour sorption isotherms measured at $25^{\circ} \mathrm{C}$ using both an automatic sorption apparatus (Bolliger, Gál \& Signer, 1972) and an isopiestic technique (Gál, 1975). The automatic sorption apparatus allows one to record weight gain curves which reflect the kinetics of the sorption process. The kinetic parameter $t_{\frac{1}{2}}$ was determined graphically from the recorded weight gain curves. It corresponds to the time required for a weight gain of one half of the total gain in each sorption step (Crank \& Park, 1968).

\section{RESULTS AND DISCUSSION}

Heat treatment of milk caused a definite change in the pattern of water adsorption of the isolated casein micelles. The equilibrium water contents of the heated preparations were markedly lower over the whole range of vapour pressures tested (Fig. 1). This result is consistent with the finding that association of heat-denatured, hydrophobic whey proteins with casein occurs on heating milk (Elfagm \& Wheelock, 1977), and that some $\mathrm{Ca}$ phosphate is removed from the micelles during heat treatments (Morr, 1975).

As judged from the amount of adsorbed water, the influence of the heating methods could be ranked in the order: HTST $\left(92^{\circ} \mathrm{C}\right) \simeq$ UHT (direct) $<$ UHT (indirect) < HTST $\left(72^{\circ} \mathrm{C}\right.$ ). The somewhat unexpected position of the HTST treatment at $72^{\circ} \mathrm{C}$ in this order can most probably be explained in terms of whey protein- 
Table 1. Mathematical analysis of water sorption isotherms of micellar caseins according to the BET equation (3)

\begin{tabular}{|c|c|c|c|}
\hline \multirow[b]{2}{*}{ Processing of milk } & \multicolumn{3}{|c|}{ Parameter (1) } \\
\hline & $\begin{array}{c}\text { Monolayer water } \\
\text { content, } X_{m}, \%\end{array}$ & $\begin{array}{l}\text { Constant related to } \\
\text { heat of adsorption, } C\end{array}$ & $\begin{array}{c}\text { Relative water vapour } \\
\text { pressure corresponding } \\
\text { to } X_{m}\left(p / p_{o}\right)\end{array}$ \\
\hline \multicolumn{4}{|l|}{ Untreated } \\
\hline $\bar{x}$ & $6 \cdot 18$ & 10.7 & 0.235 \\
\hline \pm s.p. & 0.19 & 0.4 & 0.004 \\
\hline \multicolumn{4}{|l|}{ HTST, $72^{\circ} \mathrm{C}$} \\
\hline $\bar{x}$ & 4.84 & $10 \cdot 8$ & 0.236 \\
\hline \pm S.D. & 0.21 & 2.5 & 0.018 \\
\hline \multicolumn{4}{|l|}{ HTST, $92{ }^{\circ} \mathrm{C}$} \\
\hline $\bar{x}$ & $5 \cdot 48$ & $10 \cdot 6$ & $0 \cdot 235$ \\
\hline \pm S.D. & 0.05 & 0.4 & 0.004 \\
\hline \multicolumn{4}{|l|}{ UHT, direct } \\
\hline $\bar{x}$ & $5 \cdot 14$ & $11 \cdot 4$ & 0.229 \\
\hline $\pm s .0$ & $0 \cdot 10$ & 0.4 & 0.003 \\
\hline \multicolumn{4}{|l|}{$\mathrm{UHT}$, indirect } \\
\hline $\bar{x}$ & 5.06 & $10 \cdot 1$ & 0.239 \\
\hline \pm S.D. & 0.34 & 0.7 & 0.006 \\
\hline $\begin{array}{c}\text { Analysis of varianco } \\
F \text {-value }\end{array}$ & $25 \cdot 86^{* * *}$ & $0.18 \mathrm{n.s.}$ & $0.25 \mathrm{n.s}$. \\
\hline
\end{tabular}

(1) The values were determined from the linearized segments of the isotherm in the $p / p_{0}$ range of $0 \cdot 10-0 \cdot 45$ :

$$
\frac{p / p_{0}}{X \cdot\left(1-p / p_{0}\right)}=\frac{1}{X_{m} \cdot C}+\frac{C-1}{X_{m} \cdot C} \cdot p / p_{0}(X: \% \text { water adsorbed }) \text {. }
$$

(2) $F$-values have 4 and 17 degrees of freedom; *** $P<0.001$; n.s., not significant.

(3) Brunauer, Emmett \& Teller (1938).

casein interactions. Heat induced whey protein denaturation and association with casein is much less important at $72^{\circ} \mathrm{C}$ than at the higher temperatures (Guy, Vettel \& Pallansch, 1967; Blanc, Baer \& Rüegg, 1977). Therefore, dissociation of hydrophilic micelle components during and after heat treatments could be basically different in the HTST $\left(72^{\circ} \mathrm{C}\right)$ milk.

A monolayer water content $\left(X_{m}\right)$ as defined by Brunauer, Emmett \& Teller (1938) (BET) was estimated from the lower end of the isotherms in the relative vapour pressure range of about $p / p_{o}=0 \cdot 1-0 \cdot 45$. The average monolayer water contents were lower for the heat-treated samples (Table 1). However, the constant $C$ of the $\mathrm{BET}$ equation, which is related to the heat of adsorption, was not significantly different for the 5 samples.

The kinetic parameter $t_{\frac{1}{3}}$, which showed marked discontinuities, was plotted against the amount of adsorbed water. Typical curves are shown in Fig. 2. For untreated micellar casein the $t_{\frac{z}{2}} v s$. water content curve showed a relatively simple pattern with maxima at water contents which correspond closely to multiples of the apparent BET monolayer values, i.e. $X_{m}, 2 X_{m}$ and, less pronounced, to $3 X_{m}$. The $t_{1}$ curves of the samples of heat-processed milk revealed a more complex pattern and the decrease of the sorption rate after completion of the first layer $\left(X_{m}\right)$ was less pronounced.

The calculated monolayer water contents correspond to points on the sorption isotherms at about $p / p_{0}=0 \cdot 2$. It is interesting to note that an earlier study of casein 

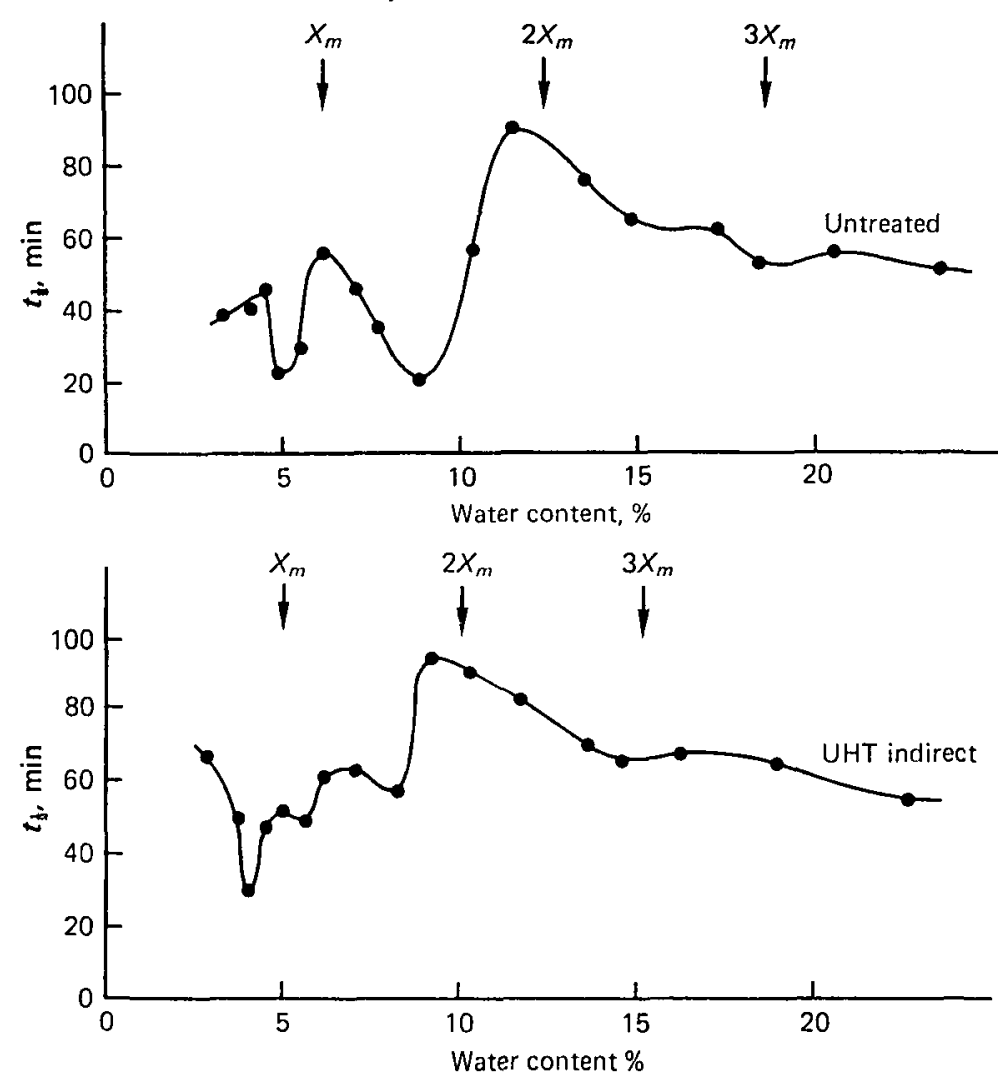

Fig. 2. Time of half saturation $\left(t_{t}\right)$ as a function of water content for water vapour sorption of micellar casein from untreated and indirect ultra-high-temperature (UHT indirect) processed milk. $X_{m}$ corresponds to the 'monolayer water content' calculated using the Brunauer-EmmetTeller (BET) equation.

hydration by infrared techniques revealed a significant change in the casein water interactions at the same $p / p_{o}$ values (Rüegg \& Häni, 1975). The coincidence of the maxima in the $t_{\frac{1}{2}}$ curves with the BET monolayer values seems to demonstrate that casein hydration occurs stepwise by formation of layers or zones of differently bound water.

We are grateful to Miss U. Moor for her careful technical assistance and to Dr M. Casey for his help in preparing the manuscript.

\section{REFERENCES}

Blanc, B., BaER, A. \& RüEgG, M. (1977). Schweizerische Milchwirtschaftliche Forschung 6, 21.

Bolitiger, W., GÁr, S. \& Signer, R. (1972). Helvetica Chimica Acta 55, 2659.

Brunauer, S., Emmetr, P. H. \& Tellen, E. (1938). Journal of the American Chemical Society 60, 309.

Crank, P. \& Park, G. S. (1968). Diffusion in Polymers. London: Academic Press.

Elfagm, A. A. \& Wheelock, J. V. (1977). Journal of Dairy Research 44, 367.

GÁL, S. (1975). In Water Relations of Foods, p. 139. (Ed. R. B. Duckworth.) London: Academic Press. Guy, E. J., Vettel, H. E. \& Pallansch, M. J. (1967). Journal of Dairy Science 50, 828.

Kuntz, I. D. \& Kadzmans, W. (1974). In Advances in Protein Chemistry, p. 239. (Eds C. B. Anfinsen, J. T. Edsall and F. A. Richards.) London: Academic Press.

MoRr, C. V. (1975). Journal of Dairy Science 58, 977.

RüEgG, M. \& Blanc, B. (1976). Journal of Dairy Science 59, 1019.

RÜEGG, M. \& HäN, H. (1975). Biochimica et Biophysica Acta 400, 17. 